\title{
Editorial Introduction: Rethinking 1968
}

\author{
KEVIN W. GRAY
}

This issue represents the culmination of two years labour. It began with a special-topics session at the annual meeting of the Society for Existential and Phenomenological Theory and Culture / Théorie et culture existentialistes et phénoménologiques (EPTC/TCEP) to commemorate the $40^{\text {th }}$ anniversary of the events of May ' 68 . The papers in this number of the journal have been chosen from the best papers presented at the conference in 2008 and in 2009 , plus a selection of those that were submitted online.

The $40^{\text {th }}$ anniversary of 1968 was the occasion for our EPTC/TCEP gathering in Vancouver as well as for many other conferences worldwide. Theorists of radical democracy in particular continue to look to the events of '68 to try to redefine the sphere of the possible, and to question the relationship between the governed and the sovereign. Broadly, articles in the volume take two different forms. Some interrogate the events of 1968 and ask what we can learn from them for the politics of today. For instance, Jean-Pierre Boulé's text discusses the difficult relationship between 1968 and contemporary French politics, comparing and contrasting the relationship between Sartre and '68 on the one hand, and '68 and Sarkozy on the other hand. Kevin W. Gray's paper argues that Habermas' essay on the revolutions of 1989 betrays his original work on the student protest movements in 1968, and the structure of the public sphere, and shows how, by rereading those early texts, we can come to a better understanding of 1989 . 
Other papers contest traditional interpretations of 1968. Drawing on personal experience and the excellent 1968 Archives he created at Simon Fraser University, Andrew Feenberg challenges traditional interpretations of the student protests by arguing that they were in fact animated by an important critique of technocracy that remains relevant today. Staying with France, Chris Reynolds shows how traditional interpretations of 1968 have ignored events in the periphery of Metropolitan France. Adrian Switzer discusses the various ways the events of 1968 were understood by French thinkers, and then substitutes his own horizontal reading of the barricades, inspired by Foucault and Deleuze.

Moving to Critical Theory, Peter-Erwin Jansen continues his important work with the Marcuse Nachlass, and discusses the influence of Freud, through Marcuse's work, on the German student protest movement. John Duncan develops the Sartrean philosophical anthropology that grounds the radical critical theory of May '68, delimits it with Foucault's posthumanism, and finds its echoes in the alternative press of today.

\section{Acknowledgments}

Every volume of PhaenEx is a group project, and this volume is certainly no exception. Many thanks go, first and foremost, to the anonymous reviewers. After that, I am indebted to each and every member of the Editorial Collective for the diligent editing work. Finally, I want to thank Peter-Erwin Jansen and the Marcuse Nachlass for their help in securing the wonderful cover image of Marcuse with a group of student protestors at UCSD. 